\title{
PENGARUH LAMA PENYIMPANAN AIR MINUM GALON TERHADAP TOTAL BAKTERI COLIFORM PADA DAM X DI DESA KARANGMANGU KECAMATAN BATURRADEN KABUPATEN BANYUMAS TAHUN 2016
}

\author{
Dian Nita Utami ${ }^{1)}$, Djamaluddin Ramlan' ${ }^{2)}$, Tri Cahyono ${ }^{3)}$ \\ Jurusan Kesehatan Lingkungan, Politeknik Kesehatan Kemenkes Semarang, \\ Jl. Raya Baturaden KM 12 Purwokerto, Indonesia
}

\begin{abstract}
Abstrak
Depot Air Minum merupakan usaha industri yang melakukan proses pengolahan air baku menjadi air minum. Berdasarkan hasil pengamatan peneliti, DAM X tidak melakukan pengeringan galon, tutup galon kontak udara bebas dan konsumen DAM X menggunakan air minum dengan lama waktu penyimpanan 2-6 hari per galon. Tujuan penelitian adalah mengetahui pengaruh lama penyimpanan air minum galon terhadap total bakteri coliform pada DAM X. Metode penelitian yang digunakan quasi experiment dengan rancangan time series design.Hasil penelitian menunjukkan bahwa rata-rata jumlah total bakteri coliform hari ke-1=1,67 MPN/100ml, hari ke-2=2,4 MPN/100ml, hari ke-3=1,47 MPN/100 ml, harike-4=1,47MPN/100 ml, hari ke-5=0,73 MPN/100 ml danhari ke$6=0 \mathrm{MPN} / 100 \mathrm{ml}$. Hasil analisis bivariate pengaruh lama penyimpanan air minum galon terhadap total bakteri coliform pada waktu pengambilan jam 06.00 diketahuinilai $R=0,284, R^{2}=0,080, p=0,293, Y=2,627+(-0,303) X$, waktu pengambilan jam 06.30 nilai $R=0,293, R^{2}=0,086, p=0,287, Y=1,760+(-0,189) X$, waktu pengambilan jam 07.00 nilai $R=0,592, R^{2}=0,350, p=0,108, Y=3,480+(-0,651) X$ dan rata-rata jumlah total bakteri coliform per hari $R=0,864, R^{2}=0,746, p=0,013, Y=2,626+(-0,382) X$. Simpulan hasil penelitian adalah ada pengaruh lama penyimpanan air minum galon terhadap total bakteri coliform pada DAM X di Desa Karangmangu Kecamatan Baturraden Kabupaten Banyumas. Disarankan pengusaha Depot Air Minum meningkatkan hygiene sanitasi tempat dan peralatan sehingga dapat mengurangi kemungkinan terjadinya pencemaran bakteri terhadap air minum.
\end{abstract}

Kata Kunci : Lama Penyimpanan, Total Bakteri Coliform

Abstract

The Influence Of Drinking Water Gallon Storage Time Towards Total Of Coliform Bacteria At DAM X In Karangmangu Village Subdistrict Baturraden Banyumas Regency Year 2016.Depot of Drinking Water is industrial work which does the process of changing raw water into drinking water. Based on the researcher's observation, DAM X did not do drying gallons, cap gallons contact to the free air and DAM X consumers used drinking water for a long time 2 - 6 days per gallon. The purpose of this research is to find out the influence of drinking water gallon storage time towards total of coliform bacteria at DAM X. The method used in this research is quasi experiment with time series design plan. The result of the research shows that the average of total of coliform bacteria first day=1,67 MPN/100ml, second day=2,4 MPN/100 ml, third day=1,47 MPN/100 ml fourth day=1,47MPN/100 ml, fifth day=0,73 MPN/100 ml and sixth day=0 MPN/100 ml, the result of bivariate analysis the influence of refill drinking water gallon storage time towards total of coliform bacteria at 06.00 is known that the value of $R=0,284, R^{2}=0,080, p=0,293, Y=2,627+(-0,303) X$, at 06.30 the value of $R=0,293, R^{2}=0,086, p=0,287$, $Y=1,760+(-0,189) X$, at 07.00 the value of $R=0,592, R^{2}=0,350, p=0,108, Y=3,480+(-0,651) X$ and the average of total of coliform bacteria per day $R=0,864, R^{2}=0,746, p=0,013, Y=2,626+(-0,382) X$. The conclusion of this research is there was an influence of drinking water gallon storage time towards total of coliform bacteria at DAM $X$ in Karangmangu village Subdistrict Baturraden Regency. The research suggests to Depot Drinking water company to increase hygiene place and equipment sanitation so that it can reduce the possibility of bacteria contamination in drinking water.

Keywords : Storage Time, Total of Coliform Bacteria

\section{PENDAHULUAN}

Air merupakan kebutuhan pokok manusia.Tanpa air manusia hanya mampu bertahan hidup 2-3 hari. Air digunakan manusia untuk memenuhi berbagai kebutuhan seperti minum, masak, mandi, cuci dan kakus. Kebutuhan manusia terhadap air minum salah satunya dapat dipenuhi oleh Depot Air Minum.Hasil pengamatan peneliti pada Depot Air Minum X yang berlokasi di Desa Karangmangu Kecamatan Baturraden ditemukan permasalahan yaitu mesin pencuci galon dibiarkan terkena udara bebas dan pada saat proses pembilasan

1) Email : diannita_utami@yahoo.com

2) Email : djamaluddinramlan@gmail.com

3) Email : statistikan@yahoo.com 
masih terdapat air hasil cucian galon. Selain itu, tutup galon dibiarkan terkena udara bebas.Hal-hal tersebut diatas dapat memungkinkan pertumbuhan bakteri coliform yang merupakan indikasi kondisi sanitasi yang kurang baik (BPOM, 2008, h. 3).

Setelah dilakukan penutupan galon, air minum galon tersebut didistribusikan kepada konsumen dan konsumen menggunakan air minum dengan masa pakai 2-6 hari per galon. Tujuan penelitian ini untuk mengetahui pengaruh lama penyimpanan air minum galon terhadap total bakteri coliform pada DAM X di Desa Karangmangu Kecamatan Baturraden Kabupaten Banyumas. Penelitian ini bertujuan untuk mengetahui pengaruh lama penyimpanan air minum galon terhadap total bakteri coliform pada DAM X di Desa Karangmangu Kecamatan Baturraden Kabupaten Banyumas.

\section{BAHAN DAN METODE}

Jenis penelitian yang digunakan adalah quasi experiment dengan rancangan penelitian time series design. Populasi pada penelitian ini adalah air minum galon di Rumah Kos Ibu Sutinah. Sampel penelitian ini adalah air minum galon yang diambil sebanyak $100 \mathrm{ml}$ dan diambil 3 kali, yaitu jam 06.00, jam 06.30 dan jam 07.00. Instrumen pengumpulan data yang digunakan adalah uji MPN Coli di laboratorium, termometer alkohol, $\mathrm{pH}$ meter dan checklist.Metode pengumpulan data yang dilakukan adalah pengamatan, pengukuran, pemeriksaan dan menghitung. Analisis yang digunakan adalah analisis univariat dengan menghitung nilai mean dan analisis bivariat menggunakan uji regresi linier sederhana.

\section{HASIL DAN PEMBAHASAN}

\section{Univariat}

\section{Total Bakteri ColiformAir Minum yang diambil dari Kran DAM X}

Hasil pemeriksaan total bakteri coliform air minum yang diambil dari kran DAM $X$ pada pengambilan ke-1, ke-2 dan ke-3 adalah 0 MPN/100 $\mathrm{ml}$, sehingga memenuhi syarat air minum sesuai dengan Peraturan Menteri Kesehatan No. 492 tahun 2010.

\section{Waktu Pengambilan Jam 06.00}

Jumlah total bakteri coliform pada hari ke-2 sebanyak 5 MPN/100 ml disebabkan oleh perkembangbiakan bakteri pada air minum akibat proses pembilasan galon yang tidak bersih (air hasil cucian masih terdapat dalam galon) dan tutup galon ditempatkan di dalam plastik yang terbuka, sehingga meningkatkan pencemaran bakteri terhadap air minum.Lingkungan tempat penyimpanan air minum galon yang kotor dapat mencemari air minum melalui mulut kran galon. Udara di suatu ruangan dalam rumah biasanya terdapat mikroorganisme, seperti: bakteri, jamur, serangga atau partikel- partikel biologi lainnya (Lily Pudjiastuti, dkk., 1998, h. 35). Selain itu, kondisi air minum dengan $\mathrm{pH} 6,9$ dan suhu $27^{\circ} \mathrm{C}$ dapat mendukung tumbuhnya bakteri karena bakteri hidup pada pH 6,5 - 7,5(M. J. Pelczar dan E.C.S. Chan, 2010,h. 140) dan suhu $25-40^{\circ} \mathrm{C}$ (Lud Waluyo, 2007, h. 130).

Jumlah total bakteri coliform pada hari ke-3 dan ke-5 sebanyak 2,2 MPN/100 ml disebabkan oleh pergerakan bakteri sehingga bakteri yang terbawa saat pengambilan hanya sedikit. Bakteri coliform termasuk dalam bakteri batang anaerobik fakultatif gram negatif yang mempunyai flagella peritrikus yaitu flagel terdapat pada seluruh permukaan sel (Sjoekoer M. Dzen, dkk, 2003, h. 18). Bakteri coliform termasuk dalam kategori bakteri anaerobik fakultatif sehingga pertumbuhan koloninya tersebar dalam medium cair (Dwidjoseputro, 1990, h. 77).

Jumlah total bakteri coliform pada hari ke-1, ke4 dan ke-6 sebanyak0 MPN/100 ml disebabkan oleh fase adaptasi yang dialami bakteri pada hari ke-1, yaitu fase menyesuaikan diri dengan lingkungan sekitarnya. Menururt Nurwanto dan Abbas Siregar (1997, h. 28), pada fase adaptasi belum terjadi pertumbuhan dan pembelahan sel, sedangkan hari ke-4 dan ke-6 tidak didapatkan bakteri, karena bakteri mempunyai pili yang berfungsi sebagai alat untuk melekat pada berbagai permukaan, sehingga dapat membantu bakteri melekatkan dirinya pada jaringan hewan atau tumbuhan yang merupakan sumber nutriennya (M.J. Pelczar dan E.C.S. Chan, 2008, h. 112).

\section{Waktu Pengambilan Jam 06.30}

Jumlah total bakteri coliform pada hari ke-2, ke3 dan ke-4 sebanyak2,2 MPN/100 ml disebabkan oleh bakteri pada air minum sudah mengalami perkem-bangbiakan, tetapi bakteri coliform mempunyai flagel untuk bergerak, sehingga bakteri yang terbawa saat pengambilan hanya sedikit. Selain itu, setelah mengalami pertumbuhan, bakteri akan membentuk suatu koloni (Sjoekoer M. Dzen, 2003, h. 27). Bakteri dalam bentuk koloni akan menyebabkan hasil pemeriksaan jumlah bakteri coliform rendah, karena uji MPN Coli hanya melihat ada tidaknya gelembung udara pada tabung durham.

Jumlah total bakteri coliform pada hari ke-1, ke5 dan ke-6 disebabkan oleh fase adaptasi yang dialami bakteri pada hari ke-1, yaitu fase menyesuaikan diri dengan lingkungan sekitarnya sehingga pada fase ini belum terjadi pembelahan sel. Menurut Nurwanto dan Abbas Siregar (1997, h. 28), lamanya fase adaptasi sangat bervariasi tergantung media dan lingkungan pertumbuhannya, sedangkan pada hari ke-5 dan ke-6 tidak didapatkan bakteri karena bakteri mempunyai pili yang berfungsi sebagai alat untuk melekat pada berbagai permukaan, sehingga dapat membantu bakteri untuk melekatkan dirinya pada jaringan hewan atau tumbuhan yang merupakan sumber nutriennya. Selain itu, berdasarkan pengamatan peneliti terlihat 
endapan pada dasar galon yang kemungkinan merupakan tempat melekatnya bakteri.

\section{Waktu Pengambilan Jam 07.00}

Jumlah total bakteri coliform pada hari ke-1 sebanyak 5 MPN/100 ml disebabkan oleh pencemaran bakteri akibat proses pencucian dan pembilasan galon yang tidak bersih (air hasil cucian masih terdapat dalam galon), sehingga bakteri mengalami fase pertumbuhan awal yang menyebabkan jumlah total bakteri coliform bertambah. Selain itu, volume awal air menyentuh tutup galon, sedangkan kemungkinan tutup galon dalam keadaan yang tidak bersih karena ditempatkan dalam plastik terbuka, sehingga kontak langsung dengan udara.Hal tersebut tidak sesuai dengan Peraturan Menteri Kesehatan No.43 tahun 2014 yang mempersyaratkan tutup galon harus baru dan bersih.Selain itu, kondisi air minum dengan $\mathrm{pH}$ 6,8 dan suhu $28^{\circ} \mathrm{C}$ dapat mendukung tumbuhnya bakteri karena bakteri hidup pada $\mathrm{pH}$ 6,5 - 7,5 (M. J. Pelczar dan E.C.S. Chan, 2010, h. 140) dan suhu 25$40^{\circ} \mathrm{C}$ (Lud Waluyo, 2007,h. 130).

Jumlah total bakteri coliform pada hari ke-4 sebanyak 2,2 MPN/100 ml disebabkan oleh perkembangbiakan bakteri karena air minum dalam galon sudah tersimpan selama 4 hari, tetapi pergerakan bakteri menyebabkan tidak terbawanya bakteri coliform pada saat pengambilan sampel. Selain itu, air minum galon dalam kondisi tertutup menyebabkan kurangnya udara untuk pertumbuhan bakteri.Menurut Srikandi Fardiaz (1997, h. 111), bakteri coliform termasuk bakteri anaerobik fakultatif yang pertumbuhannya lebih baik pada kondisi aerobik daripada kondisi anaerobik.

Jumlah total bakteri coliform pada hari ke-2, ke3, ke-5 dan ke-6 sebanyak 0 MPN/100 ml disebabkan oleh volume air minum pada hari ke-2 dan ke-3 masih banyak, sehingga pergerakan bakteri dalam air minum galon luas, sedangkan hari ke-5 dan ke-6 tidak didapatkan bakteri karena pada hari ke-5 dan ke-6 pergerakan air dalam galon sudah stabil yang menyebabkan bahan organik mengendap di dasar galon, sehingga bakteri bergerak menggunakan flagel dan melekat menggunakan pili pada sumber nutrient atau makanan menuju dasar galon.

\section{Rata-rata Jumlah Total Bakteri Coliform per hari}

Hasil pemeriksaan total bakteri coliform air minum galon diketahui bahwa hari ke-1 merupakan waktu awal pertumbuhan bakteri karena mesin pencuci galon kontak dengan udara bebas danpada saat pembilasan tidak dilakukan pengeringan, sehingga masih terdapat air hasil cucian galon. Selain itu, tutup galon ditempatkan pada plastik terbuka yang dapat meningkatkan terjadinya pencemaran air minum dalam galon.Menurut Peraturan Menteri Kesehatan No.43 tahun 2014, setiap galon yang telah diisi langsung diberi tutup yang baru dan bersih.

Bakteri coliform mulai mengalami perkembangbiakan pada hari ke-2, tetapi saat pengambilan sampel jam 07.00 tidak didapatkan bakteri karena pergerakan bakteri.Bakteri coliform termasuk dalam bakteri batang anaerobik fakultatif gram negatif yang mempunyai flagella peritrikus yaitu flagel terdapat pada seluruh permukaan sel (Sjoekoer M. Dzen, dkk, 2003, h. 18).Selain itu, bakteri coliform termasuk dalam kategori bakteri anaerobik fakultatif yang pertumbuhan koloninya tersebar dalam medium cair (Dwidjoseputro, 1990, h. 77).

Jumlah bakteri coliform mengalami penurunan pada hari ke-3 disebabkan oleh keterbatasan bahanbahan organik pada air minum karena air produk sudah melalui beberapa tahap pengolahan, sehingga kualitasnya sesuai dengan Peraturan Menteri Kesehatan No. 492 tahun 2010 yang menyatakan bahwa kadar maksimum zat organik pada air minum adalah $10 \mathrm{mg} / \mathrm{l}$, sedangkan bakteri pada air minum sangat membutuhkan bahan-bahan organik sebagai sumber nutrien (Lud Waluyo, 2007, h. 89).

Pada hari ke-4 pertumbuhan bakteri coliform stabil karena air minum galon masih mengandung bahan organik yang dapat digunakan sebagai sumber energi untuk pertumbuhan sel, tetapi terjadi persaingan antar bakteri coliform dalam mendapatkan bahan organik, sehingga menyebabkan jumlah bakteri yang mati sama dengan jumlah yang hidup. Menurut Lud Waluyo (2007, h. 131), kebutuhan makanan yang sama dapat menyebabkan terjadinya persaingan antar mikroorganisme untuk mendapatkan makanannya.

Perkembangan bakteri pada hari ke-5 dan ke-6 mulai mengalami penurunan yang signifikan karena jumlah bahan organik terbatas.Selain itu, pergerakan air yang stabil dapat menyebabkan bahan organik mengendap di dasar galon, sehingga bakteri bergerak menggunakan flagel mengarah ke dasar galon dan pili untuk melekat di dasar galon.Menurut M. J. Pelczar dan E.C.S. Chan (2008, h. 112), pili berfungsi sebagai alat untuk melekat pada berbagai permukaan, sehingga dapat membantu bakteri untuk melekatkan diri pada jaringan hewan atau tumbuhan yang merupakan sumber nutriennya.

Secara keseluruhan dapat diketahui bahwa terdapat kemungkinan bakteri coliform hidup di dalam air minum galon karena $\mathrm{pH}$ air minum berkisar 6,8 - 7,1 mendukung tumbuhnya bakteri. Menurut M. J. Pelczar dan E. C. S. Chan (2010, h. 140), bakteri dapat hidup pada $\mathrm{pH}$ 6,5 - 7,5. Suhu air minum berkisar $26-28^{\circ} \mathrm{C}$ juga mendukung tumbuhnya bakteri pada air minum.Menurut Lud Waluyo (2007, h. 130), bakteri coliform termasuk dalam kelompok bakteri mesofil yang dapat tumbuh pada kisaran suhu $25-40^{\circ} \mathrm{C}$. Selain itu, terdapat halhal yang dapat mempengaruhi hasil pemeriksaan total bakteri coliform, yaitu kontaminasi pada saat 
pengambilan sampel disebakan oleh udara di tempat pengambilan sampel. Menurut Lud Waluyo (2007, h. 63), kontaminasi bakteri dapat berasal dari udara yang mengandung banyak mikroorganisme.Kondisi ruangan, alat dan media pada saat pemeriksaan bakteri juga dapat menyebabkan pencemaran bakteri terhadap air minum. Menurut Lud Waluyo (2007, h. 62), bahan dan peralatan yang dipergunakan dalam bidang mikrobiologi harus dalam keadaan steril artinya tidak terdapat mikroba yang tidak diharapkan kehadirannya baik yang menggangu atau merusak media dan proses yang sedang dikerjakan.

Hal-hal yang dapat menghambat terbawanya bakteri pada saat pengambilan sampel, yaitu pergerakan bakteri yang mengarah pada sumber nutrien dan sifat bakteri yang menempel pada berbagai permukaan. Selain itu, sumber air bakuDAM X berasal dari mata air. Menurut I Wayan Arthana (2007, h. 2), air yang berasal dari mata air mempunyai kualitas yang baik, sehingga umumnya digunakan sebagai sumber air minum oleh masyarakat sekitarnya. Air baku tersebut akan diolah melalui beberapa tahap, salah satunya desinfeksi menggunakan sinar UV. Sinar UV akanmembunuh bakteri apabila intensitas dan waktu penyinarannya cukup, sehingga air minum yang dihasilkan memenuhi syarat yang ditentukan Peraturan Menteri Kesehatan No. 492 tahun 2010. Semakin baik kualitas air minum maka semakin kecil kemungkinan bakteri dapat hidup pada air minum.

Pengusaha Depot Air Minum sebaiknya melakukan upaya untuk mengurangi kemungkinan terjadinya pencemaran bakteri terhadap air minum dengan cara menempatkan mesin pencuci galon dalam ruang tertutup, tutup galon ditempatkan dalam wadah tertutup, sehingga tutup galon terhindar dari pencemaran bakteri terhadap air minum dan ruang pengisian galon selalu dalam keadaan bersih dari barang-barang seperti tutup galon, pisau dan lap. Selain itu, sterilisasi galon menggunakan air bersih dengan suhu $60-85^{\circ} \mathrm{C}$.Peraturan yang mengatur tentang persyaratan hygiene sanitasi Depot Air Minum dapat dilihat pada Keputusan Menteri Perindustrian dan Perdagangan No. 651 tahun 2004 dan Peraturan Menteri Kesehatan No. 43 tahun 2014.

Upaya yang dapat dilakukan masyarakat untuk mencegah pencemaran bakteri terhadap air minum, yaitu pemberian tutup pada kran galon, sehingga mencegah masuknya debu atau kotoran melalui mulut kran dan membersihan bagian permukaan galon dengan tisu pembersih sebelum penyimpanan air minum galon. Selain itu, perlu diperhatikan penempatan air minum galon, sehingga tidak terkena langsung sinar matahari.Menurut Indan Entjang (2003, h.92) terdapat bakteri yang pertumbuhannya bergantung pada sinar matahari.

\section{Bivariat}

Hasil analisis bivariat mengenai pengaruh lama penyimpanan air minum galon terhadap total bakteri coliformwaktu pengambilan jam 06.00 menggunakan uji regresi linier sederhana diperoleh nilai $p$ sebesar $0,293>0,05$ (nilai $\alpha$ ) yang dapat diartikan tidak ada pengaruh lama penyimpanan air minum galon terhadap total bakteri coliform. Persamaan garis dari hasil analisis yaitu $\mathrm{Y}=2,627+$ (- 0,303) X yang menyatakan bahwa setiap pengurangan 1 hari lama penyimpanan akan meningkatkan total bakteri coliform sebesar 0, 303 .

Hasil analisis pengaruh lama penyimpanan air minum galon terhadap total bakteri coliform waktu pengambilan jam 06.30 diperoleh nilai p sebesar $0,287>0,05$ (nilai $\alpha$ ) yang dapat diartikan tidak ada pengaruh lama penyimpanan air minum galon terhadap total bakteri coliform.Persamaan garis dari hasil analisisyaitu $\mathrm{Y}=1,760+(-0,189) \mathrm{X}$ yang menyatakan bahwa setiap pengurangan 1 hari lama penyimpanan akan meningkatkan total bakteri coliform sebesar 0,189.

Hasil analisis pengaruh lama penyimpanan air minum galon terhadap total bakteri coliform waktu pengambilan jam 07.00 diperoleh nilai p sebesar $0,108>0,05$ (nilai $\alpha$ ) yang dapat diartikan tidak ada pengaruh lama penyimpanan air minum galon terhadap total bakteri coliform.Persamaan garis dari hasil analisisyaituY $=3,480+(-0,651) X$ yang menyatakan bahwa setiap pengurangan 1 hari lama penyimpanan akan meningkatkan total bakteri coliform sebesar 0,651 .

Hasil analisis pengaruh lama penyimpanan air minum galon terhadap total bakteri coliform rata-rata jumlah total bakteri coliform per hari diperoleh nilaip sebesar $0,013<0,05$ (nilai $\alpha$ ) yang dapat diartikan ada pengaruh lama penyimpanan air minum galon terhadap total bakteri coliform.Persamaan garis dari hasil analisisyaitu $\mathrm{Y}=$ $2,626+(-0,382) X$ yang menyatakan bahwa setiap pengurangan 1 hari lama penyimpanan akan meningkatkan total bakteri coliform sebesar 0,382.

Berdasarkan hasil uji statistik yang dilakukan dapat disimpulkan ketiga nilai $\mathrm{p}>$ nilai $\alpha(0,05)$, sehingga Ho diterima atau tidak ada pengaruh lama penyimpanan air minum galon terhadap total bakteri coliform, sedangkan hasil uji statistik rata-rata jumlah total bakteri coliform per hari diperoleh nilai $\mathrm{p}<$ nilai $\alpha(0,05)$, sehingga Ho ditolak atau ada pengaruh lama penyimpanan air minum galon terhadap total bakteri coliform.

Penelitian yang dilakukan sebelumnya oleh Wahyurini Ekawati (2005) dengan judul perbedaan jumlah Escherichia coli pada air minum berdasarkan lama penyimpanan pada Depot Air Minum di Kabupaten Sragen diperoleh hasil lama penyimpanan 7 hari $=0-4 \mathrm{MPN} / 100 \mathrm{ml}$, lama penyimpanan 7 hari dan lama penyimpanan 10 hari = 3-9 MPN/100 ml. Hasil penelitian menunjukan nilai t hitung hari ke-7 adalah 4,41 dengan $t$ tabel 2,36. Nilai t hitung hari ke-10 adalah 9,37 dengan $t$ tabel $=2,36$ karena $\mathrm{t}$ hitung $>\mathrm{t}$ tabel dapat disimpulkan bahwa hipotesa penelitian diterima atau 
ada perbedaan jumlah Escherichia coli pada air minum dengan lama penyimpanan yang berbeda.Hasil penelitian yang dilakukan oleh Wahyuni Ekawati jauh berbeda dengan hasil penelitian peneliti, karena pada penelitian peneliti terdapat hal-hal yang menyebabkan tidak adanya bakteri coliform pada air minum galon:

1. Kualitas awal air minum Depot Air Minum X memenuhi syarat mikrobiologi, sehingga dapat menghambat pertumbuhan bakteri. Selain itu, air minum sudah mengalami beberapa tahap pengolahan, sehingga air minum memenuhi standar yang ditentukan Peraturan Menteri Kesehatan No. 492 tahun 2010 meliputi kualitas fisik, kimia, biologi dan radiokatif.

2. Air minum pada galon dalam kondisi tertutup, sehingga menyebabkan kurangnya udara untuk pertumbuhan bakteri. Menurut Srikandi Fardiaz (1997, h. 111), bakteri coliform termasuk bakteri grup anaerobik fakultatif yang pertumbuhannya lebih baik pada kondisi aerobik daripada keadaan anaerobik.

3. Pergerakan dan sifat bakteri yang melekat pada berbagai permukaan akan menghambat terbawanya bakteri pada saat pengambilan sampel. Menurut Menurut M. J. Pelczar dan E.C.S. Chan (2008, h. 169), bakteri coliform memiliki flagela secara merata tersebar di seluruh permukaan sel (peritrikus). Selain itu, bakteri mempunyai pili yang berfungsi sebagai alat untuk melekat pada permukaan, sehingga dapat membantu bakteri untuk melekatkan dirinya pada jaringan hewan atau tumbuhan yang merupakan sumber nutrien.

\section{SIMPULAN DAN SARAN}

\section{Simpulan}

Jumlah total bakteri coliform air minum yang diambil dari kran DAM X adalah 0 MPN/100 ml.

Jumlah total bakteri coliform air minum yang diambil dari galon dengan lama penyimpanan 6 hari didapatkan hasil hari ke-1 berkisar 0-5 MPN/100 $\mathrm{ml}$, hari ke-2 berkisar0-5 MPN/100 ml, hari ke-3 berkisar 0-2,2 MPN/100 ml, hari ke-4 berkisar 0 2,2MPN/100 ml,, hari ke-5 berkisar 0-2,2 MPN/100 $\mathrm{ml}$ dan hari ke-6 yaitu 0 MPN/100 ml.

Waktu awal terjadinya pertumbuhan bakteri coliform pada air minum galon adalah hari ke-1 waktu pengambilan jam 07.00 sebanyak 5 MPN/100 $\mathrm{ml}$.

Ada pengaruh lama penyimpanan air minum galon terhadap total bakteri coliform karena nilai $\mathrm{p}$ (rata-rata jumlah total bakteri coliform per hari) < nilai $\alpha$ dengan hasil analisis sebagai berikut:

1. Waktu pengambilan jam 06.00 diperoleh nilai $\mathrm{R}$ $=0,284, R^{2}=0,080, p=0,293$ danY $=2,627+$ $(-0,303) \mathrm{X}$.
2. Waktu pengambilan jam 06.30 diperoleh nilai $\mathrm{R}$ $=0,293, \mathrm{R}^{2}=0,086, \mathrm{p}=0,287$ danY $=1,760+$ $(-0,189) \mathrm{X}$.

3. Waktu pengambilan jam 07.00 diperoleh nilai $\mathrm{R}$ $=0,592, \mathrm{R}^{2}=0,350, \mathrm{p}=0,108$ danY $=3,480+$ $(-0,651) \mathrm{X}$.

4. Rata-rata jumlah total bakteri coliform per hari diperoleh nilai $\mathrm{R}=0,864, \mathrm{R}^{2}=0,746, \mathrm{p}=0,013$ dan $\mathrm{Y}=2,626+(-0,382) \mathrm{X}$

\section{Saran}

\section{Bagi Pengusaha Depot Air Minum}

Peneliti menyarankan mesin pencuci galon ditempatkan pada ruangan tertutup, melakukan sterilisasi galon menggunakan air bersih dengan suhu $60-85^{\circ} \mathrm{C}$, tutup galon diletakan pada wadah tertutup, ruang pengisian air minum bersih dari barang-barang seperti tutup galon bekas, pisau dan lap, mulut kran galon dilengkapi dengan penutup.

\section{Bagi Masyarakat}

Peneliti menyarankan membersihan bagian permukaan galon air minum dengan tisu pembersih, kran air selalu dalam keadaan tertutup apabila tidak digunakan, memperhatikan penempatan air minum galon di ruangan sehingga tidak terkena langsung sinar matahari.

\section{DAFTAR PUSTAKA}

Anastasia E.P.W, 2010, Evaluasi Potensi Mata Air Kebutuhan Air Domestik di Kecamatan Cangkringan Kabupaten Sleman Pasca Erupsi Merapi 2010,Yogyakarta : Universitas Gajah Mada.

Asmadi, dkk, 2011, Teknologi Pengolahan Air Minum, Yogyakarta: Gosyen Publishing.

Athena, Sukar dkk, 2004, Kandungan Bakteri Total Coli dan E.coliatau Fecal Coli Air Minum dari Depot Air Minum Isi Ulang di Jakarta Tangerang dan Bekasi,Jakarta: Balai Penelitian dan Pengembangan Kesehatan Depkes RI.

Dwidjoseputro, 1990, Dasar-dasar Mikrobiologi, Malang: Djambatan.

Dwi Lestari, 2014, Santasi dan Kualitas Bakteriologis Air Minum pada Depot Air Minum Isi Ulang (DAMIU) di Kecamatan Kalimanah Kabupaten Purbalingga Tahun 2014, Purwokerto: Jurusan Kesehatan Lingkungan.

Firdaus Yustisia S.,Manajemen Pengawasan Sanitasi Lingkungan dan Kualitas 
Bakteriologis pada Depot Air Minum Kota Batam, Medan: Universitas Sumatra Utara.

Herwanti, 2013, Studi Kualitas Bakteriologi Depot Air Minum Isi Ulang (DAMIU) di Wilayah Kerja Puskesmas Purwokerto Selatan Kabupaten Banyumas Tahun 2013, Purwokerto: Jurusan Kesehatan Lingkungan.Hiasinta A. Purnawijayanti, 2001, Sanitasi Higiene dan Keselamatan Kerja dalam Pengolahan Makanan, Jakarta: Kanisius.

Indan Entjang, 2003, Mikrobiologi dan Parasitologi, Bandung: PT.Citra Aditya Bakti.

I Wayan Arthana, 2007, Studi Kualitas Air pada Beberapa Mata Air Sekitar Bedugul, Denpasar: Universitas Udayana.

Lily Pudjiastuti, dkk, 1998, Kualitas Udara Dalam Ruang, Jakarta: Direktorat Jendral Pendidikan Tinggi Departemen Pendidikan dan Kebudayaan.

Lud Waluyo, 2007, Mikrobiologi Umum, Malang: UMM Press.

Lud Waluyo, 2009, Mikrobiologi Lingkungan, Malang: UMM Press.

Pelczar, Michael J., E.C.S. Chan, 2010, Dasar-dasar Mikrobiologi 1, Jakarta: UI Press.

, 2008, Dasar-dasar Mikrobiologi 2, Jakarta: UI Press.
Nurwanto, Abbas Siregar D., 1997, Mikrobiologi Pangan Hewani-Nabati, Yogyakarta: Kanisius.

Nusa Idaman Said, 2008, Teknologi Pengolahan Air Minum, Jakarta: Pusat Teknologi Lingkungan.

Palupi Widyastuti, Apriani, 2011, Pedoman Mutu Air Minum. Jakarta: EGC.

Pracoyo Noer Endah, 2006, Penelitian Air Minum Isi Ulang di Daerah Jabodetabek, Jakarta: Departemen Kesehatan Republik Indonesia.

Rabiatul Al Adawiyah, 2014, Gambaran Jumlah BakterEscherichia coli pada Air Minum Isi Ulang (AMIU) Sumber Depot Berdasarkan Lama Penggunaan pada Penguhuni Kos Smart Center Kota Gorontalo Tahun 2014,Gorontalo: Universitas Negeri Gorontalo.

Sjoekoer M. Dzen, 2003, Mikrobiologi Medik, Malang: Fakultas Kedokteran Universitas Brawijaya.

Srikandi Fardiaz, 1992, Mikrobiologi Pangan 1, Jakarta: PT.Gramedia Pustaka Utama.

Setijo Pijoto dan Eling Purwantoyo, 2003, Deteksi Pencemaran Air Minum, Semarang: Aneka Ilmu.

Totok Sutrisno dan Eni Suciati, 2010, Teknologi Penyediaan Air Bersih, Jakarta: Rineka Cipta. 